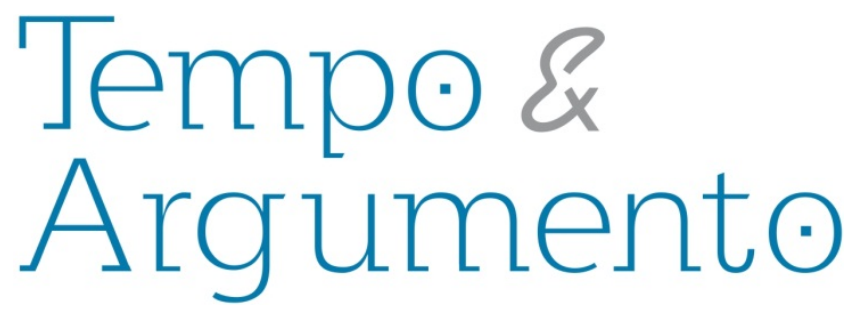

\title{
Ciência e hereditariedade na história de um assassino em série: em busca do gene perdido de Febronio
}

\begin{abstract}
Resumo
Este artigo pretende analisar a relação entre alcoolismo e hereditariedade a partir do estudo de caso do conhecido assassino em série da década de 1920, Febronio Indio do Brasil. Inicialmente, pretendemos mostrar 0 desenvolvimento da conduta criminal de Febronio no periódico Correio da Manhã e a construção da imagem de um indivíduo propenso à criminalidade. Tal questão nos levará à análise do Boletim Anti-alcoolico que, em circulação em 1929, explicaria a condição de Febronio por consequência do alcoolismo paterno, gestando um indivíduo propenso à criminalidade. Assim, características hereditárias foram apontadas como causadoras de seu desvio de conduta. Portanto, observaremos os discursos médicos e científicos da época na tentativa de explicar a hereditariedade de Febronio e suas motivações criminais, principalmente em vista de discurso de um campo mais amplo composto por médicos, antropólogos e cientistas que desenvolveram trabalhos na área de criminologia, um interesse recorrente no pensamento científico do período.
\end{abstract}

Palavras-chave: BRASIL, Febronio Indio do; Alcoolismo e crime; Hereditariedade; Assassinos; Homicidas em série.

\author{
Leonardo Dallacqua de Carvalho \\ Doutorando em História das Ciências e da \\ Saúde na Casa de Oswaldo Cruz - FIOCRUZ/RJ. \\ Brasil \\ leo_gerrard@hotmail.com
}

\section{Breno Sabino Leite de Souza}

Doutorando em História das Ciências e da Saúde na Casa de Oswaldo Cruz - FIOCRUZ/RJ. Brasil breno.sabino@hotmail.com

\section{Para citar este artigo:}

CARVALHO, Leonardo Dallacqua de; SOUZA, Breno Sabino Leite de. Ciência e hereditariedade na história de um assassino em série: em busca do gene perdido de Febronio. Revista Tempo e Argumento, Florianópolis, v. 8, n. 18, p. 385 - 410. maio/ago. 2016. 


\title{
Science and inheritance in the history of a serial killer: the search for the lost gene of Febronios
}

\begin{abstract}
This article aims to analyze the relationship between alcoholism and heredity from the case study of the killer known in the 1920 s series, Febronio Indio do Brasil. Initially, we intend to show the development of criminal conduct Febronio in the journal Correio da Manhã and the construction of the image of an individual prone to crime. This question will lead to analysis of the Anti-alcoholic Bulletin in circulation in 1929, explain the condition Febronio consequently the paternal alcoholism, gestating an individual prone to crime. Thus, hereditary characteristics were highlighted as causes of his misconduct. Therefore, we observe the medical and scientific discourse of the time in an attempt to explain the heredity of Febronio and their criminal motivations, especially in view of a wider field speech made by medical anthropologists and scientists who developed work in criminology area, a recurring interest in scientific thinking of the period.
\end{abstract}

Keywords: BRASIL, Febronio Indio; Alcoholism and crime; Heredity; Assassins; Serial killers.

"Quem usa bebidas alcoólicas candidata-se a ser pai de Febronio." (LBHM, 1929, p. 7)

Febronio Indio do Brasil, famoso assassino em série que frequentou as páginas da imprensa nacional na década de 1920 foi notado na historiografia por diferentes enfoques de pesquisadores que possuíam como perspectiva estudos sobre a loucura, o poder e a criminalidade (GUTMAN, 2010; CASOY, 2009). Tais questões podem ser percebidas tanto em vertentes foucaultianas e a sua relação com a loucura, como no estudo de Guilherme 
Gutman, como em uma narrativa de caso, ao exemplo do livro de llana Casoy. A presente investigação pretende seguir outra direção, enfatizando a questão médica do fator hereditário utilizada para o caso de Febronio, especialmente, restringida na proximidade entre hereditariedade e alcoolismo. Essa questão propõe como consequência uma suposta "degeneração do indivíduo" por conta do uso do álcool, podendo levá-lo à criminalidade e a transmitir hereditariamente o "gene do crime". Compreender esse discurso empregado no controle social de Febronio permite entender os instrumentos do Estado nas tentativas de normatização da sociedade, sobretudo, por meio de um discurso médico especializado.

A literatura dedicada à figura de Febronio esteve presente em autores como Peter Fry (1982; 1985) e João Silvério Trevisan (2004), substancialmente voltada à discussão em torno da homossexualidade de Febronio. Embora seja uma análise relevante, uma outra faceta da discussão está presente na interpretação de que Febronio estaria predisposto à criminalidade. Esta hipótese que procuramos desenvolver diz respeito ao modo como Febronio foi apresentado no molde de suposto criminoso nato, em que seus delitos eram originados por consequência de uma hereditariedade nociva, fruto do alcoolismo do seu pai. Para isso, utilizamos como fonte o Boletim Anti-alcoolico, publicado e editado pela Liga Brasileira de Higiene Mental em junho de 1929, Ano 1, n. 1. Este documento está presente no Fundo Pessoal Belisário Penna, na Casa de Oswaldo Cruz ${ }^{1}$. Em concordância, trabalharemos com notícias do impresso periódico Correio da Manhã (1920-1929), na expectativa de desenhar um perfil cronológico e criminal da personagem. Ao observar as notícias vinculadas no Correio da Manhã, podemos ter a dimensão de como sua imagem foi construída enquanto criminoso e pensar o seu lugar no contexto em que viveu.

Apesar do nosso objeto de análise dialogar com os temas da loucura e psiquiatria, pretendemos focar no exame da hereditariedade e alcoolismo. As fontes e objetivos propostos permitem restringir a centralidade da questão na concepção eugênica de hereditariedade que ecoava na Liga Brasileira de Higiene Mental (LBHM). Trataremos de alguns pontos acerca da degeneração e psiquiatria, porém, nossa maior contribuição

${ }^{1}$ Este documento está presente no Fundo Pessoal de Belisário Penna na Casa de Oswaldo Cruz. Agradecemos ao apoio da Casa de Oswaldo Cruz e da Biblioteca de Manguinhos durante a pesquisa. 
almeja ser na discussão da hereditariedade. Além disso, ao destacarmos o neolamarckismo como corrente explicativa por parte da comunidade científica, para o caso da hereditariedade de Febronio, expomos como esta corrente trafegava nas interpretações médicas do período. Por último, foi uma opção delimitar este quadro de investigação por convergir com pesquisas em andamento que têm como enfoque a relação entre o álcool e a hereditariedade, principalmente atrelada ao grupo médico participante da LBHM.

\section{A anatomia contextual da discussão}

A ligação entre crime e criminoso pertenceu à atmosfera do pensamento científico e motivou estudos sobre o indivíduo em diferentes vertentes. Assim, ramificaram-se investigações nos aspectos biológicos, psicológicos, hereditários ou sociais, pois o organismo poderia indicar pistas dos "tipos humanos" que ele representava e o seu grau de periculosidade para a sociedade. Sobretudo, o século XIX trouxe grande inquietação no estado do saber das ciências que, em partes, se voltaram para uma percepção mais acurada e criações de instrumentos para auxiliar a criminologia.

A rigor, o desenvolvimento de técnicas no estabelecimento científico contribuiu para os esforços em desvendar a categoria de indivíduo criminoso. Na segunda metade dos oitocentos, a escola de criminologia italiana lançou mão da tese do criminoso nato, elaborada pelo cientista Cesare Lombroso, possivelmente um dos maiores expoentes daquela interpretação. Em seu livro intitulado Criminal Man, entre as ideais defendidas, estaria o argumento de que a criminalidade poderia estar associada à hereditariedade, com relevância na biotipologia humana ou mesmo em questões psicológicas. Portanto, medições antropométricas em orelhas ou nariz poderiam oferecer indícios de padronização e normatização na busca de indivíduos socialmente perigosos. No que diz respeito ao caráter da normatização, George Canguilhem (2009, p. 92) assevera que a consequência da padronização de um tipo ou conduta considerada "normal" ocasiona o repúdio ou afastamento de tudo aquilo que passa a ser classificado como "anormal". 
Como salienta o autor em relação às normas, elas "exprimem discriminações de qualidades de acordo com a oposição polar de um positivo e de um negativo".

Para entender melhor a discussão e sua presença nesse período, o estudo realizado pela historiadora Ana Carolina Vimieiro Gomes sobre a fisiologia na virada do século XIX, ilumina a questão ao mostrar o desenvolvimento da instrumentalização e normatização na disciplina por meio do discurso do cientista francês Claude Bernard:

Uma ciência baseada na observação seria a constatação dos fenômenos tal como a natureza comumente nos apresenta, portanto passiva, diferente da baseada na experimentação, então ativa, que, embora envolvesse a observação, seria a constatação dos fenômenos criados e determinados intencionalmente pelo investigador. Por isso, segundo Bernard tais fenômenos seriam provocados artificialmente com auxílio de instrumentos e outros meios de intervenção no corpo e, no caso da fisiologia, com o intuito de empreender uma comparação dos fatos, isto é, dos fenômenos em estado normal e anormal. (GOMES, 2009, p. 36)

Na mesma época, o cientista inglês Francis Galton, conhecido por formular as bases da eugenia, seria responsável por realizar trabalhos sobre sulcos das impressões digitais humanas, uma ferramenta que contribuiu na linha estrutural da identificação de criminosos. Em Finger Prints, o Galton explicou como as digitais poderiam ser utilizadas como uma forma de identidade pessoal. Aliás, o uso de impressões digitais possuiu um contexto chave no curso de dominação inglesa, enquanto nação hegemônica, no processo imperialista de colonização da Índia. Ou seja, a leitura de ciência não pode ser entendida como algo neutro, apenas direcionada a um suposto progresso científico, mas alinhada a interesses dos mais diversos. A ciência em ação do século XIX, em especial na sua segunda metade, seria observada ainda nos estudos de Herbert Spencer, nos exames de crânio de Paul Broca, e no best-seller de Charles Darwin, A Origem das Espécies. O período foi marcante por florescer uma enorme quantidade de trabalhos que potencializariam uma visão central do indivíduo como foco de análise.

Este apanhado geral do século XIX permite identificar o empreendimento de parte da comunidade científica na observação do indivíduo e suas ações específicas na sociedade. Embora seja um erro afirmar que o estudo humano esteja exclusivamente 
ligado em esforços para resolver os problemas da criminalidade, a sociedade da qual eram participantes forjava um contexto para o tratamento mais específico sobre os indivíduos e a criação de padrões de "tipos humanos". Uma sociedade caótica deveria ser controlada pelas autoridades daquele espaço e tempo, personificadas na ação do Estado ou das ciências.

A título de exemplo, em Guerra contra os fracos, Edwin Black (2003, p. 58) destacou como o assassino em série conhecido como Jack, O Estripador, causou um verdadeiro problema social no East End de Londres. Para agravar, além do medo, havia uma inquietação de múltiplos crimes ocorrendo por todo o país e a dificuldade em identificar os criminosos e controlar o caos. É importante salientar que apesar de estarmos focados na conduta da criminalidade associada aos fatores hereditários, característica no caso de Febronio, todavia, a dita normatização ou padronização esteve presente em diversas demandas sociais e discussões do período. Ela não constituiu um objeto exclusivo dos indivíduos ditos criminosos.

Um referencial pertinente para ilustrar essa observação encontra-se na personagem Adda Jurke. Esta mulher inglesa considerada bêbada, ladra e avessa ao trabalho tornou-se um símbolo em parte do meio médico especializado como um sinônimo de ser humano "degenerado". Por meio de estudo de sua genealogia, identificaram uma descendência familiar composta de degenerados que explicariam por que Adda Jurke havia chegado naquele estágio indesejável. O pesquisador Fernando Sérgio Dumas dos Santos (SANTOS; VERANI, 2010, p. 406) averiguou que o caso de Jurke foi discutido até mesmo no Brasil. Sob a voz do médico sanitarista Belisário Penna, por exemplo, ele afirmou que por quase um século a família de Adda Jurke teria gestado pessoas moralmente degeneradas. O famoso eugenista brasileiro Renato Kehl também revelou preocupação com o caso. Em Eugenia e Medicinal Social (1923, p. 91) notou que a inglesa era um arquétipo perfeito de decadência hereditária. Ao utilizar informações do próprio Belisário Penna, Renato Kehl sublinhou que na descendência de 843 indivíduos poderiam ser observados 76 criminosos, dos quais sete eram assassinos.

A historiografia tem privilegiado em grande parte os estudos da aproximação entre as concepções de loucura, criminalidade e degeneração. Os trabalhos de Sergio 
Carrara $(1996 ; 1998)$ ofereceram um suporte metodológico na compreensão de como a patologização estaria implicada "[...] em toda uma longa série de comportamentos desviantes - homossexualidade, prostituição, alcoolismo, etc. - que continuam a ser até hoje objetos privilegiados da reflexão sociológica".

Além do campo científico, deve-se olhar para o contexto e negociações sociais da formulação dessas teorias. Se nos atentarmos aos escritos de Foucault (1972, p. 414), o autor faz referência quanto aos aspectos de classes e grupos que dominam a sociedade e, consequentemente, são responsáveis por moldarem seus padrões. Não à toa, mostrou que a loucura foi atribuída, muitas vezes, como consequência daquelas classes que abandonaram as formas da ética burguesa. Nelas estariam inclusos os excessos de bebidas alcoólicas e as taras venéreas. O historiador Sidney Chalhoub (1996), por sua vez, lembra que no Brasil, negros e pobres foram classificados como classes perigosas, uma atribuição de padronização daqueles estereótipos considerados problemáticos para a sociedade. Dessa forma, com relação ao caso de Febronio, notaremos que um certo padrão forjado de indivíduo colaborou para o diagnóstico referente às questões de hereditariedade. Tal questão vista por meio das fontes de impressos, endossam o argumento de Ana Vasconcelos Ottoni (2012, p. 303), de que repórteres "justificavam a criminalidade sob o argumento de que os negros eram pobres ou ainda apelavam para uma pretensa 'natureza' ou à raça". Hereditariedade e raça estiveram na ótica do caso de Febronio e nas discussões contextuais do Brasil.

Além do estereótipo social, o caso de Febronio suscitou uma ampla discussão em diversas áreas do conhecimento da época, especialmente em grupos de médicos e psiquiatras. Na percepção do aspecto hereditário, uma gama de teóricos foi selecionada na tentativa de identificar as motivações da criminalidade de Febronio. As compreensões desses intelectuais no caráter degenerativo do álcool estiveram fundadas, muitas vezes, em bases dos estudos de teóricos da psiquiatria como Bénédic Morel (1809-1873), Valentin Magnan (1835-1916) na proposta da correlação entre herança mórbida relacionada ao alcoolismo e à criminalidade. Este ponto é destacado na perspectiva de que muitos médicos e psiquiatras da Liga Brasileira de Higiene Mental perceberam a importância dos estudos hereditários desses autores para os seus estudos. 
Nessa conjuntura, o meio representou uma interpretação agravante para a constituição biológica do indivíduo. Alguns intelectuais acreditavam que o meio atuaria como um agente modelador e transformador do físico e mental da população, e tais modificações, maléficas ou benéficas, eram transmitidas para a descendência. No que concerne às ideias ambientalistas e às disposições dos adeptos aos chamados neolamarckismo, a pesquisadora Sandra Caponi (2012, p. 138), asseverou como essa corrente teve um caráter interpretativo particular no século XIX e permaneceu nas teses de uma parcela médica e intelectual no século seguinte. A autora pontua que esses especialistas "tentavam elaborar explicações acreditáveis e bem fundadas dos fenômenos hereditários, que permitissem integrar os fatos sociais e as teorias da herança, então aceita pela comunidade científica". Ao entender a atmosfera desse pensamento presente nas décadas iniciais dos novecentos, podemos agora nos abreviar ao recorte temporal mais preciso do caso de Febronio, especialmente na construção de sua narrativa em impressos periódicos.

\section{A trajetória do "filho da luz" no correio da manhã}

No livro Serial Killers: made in Brasil, a jornalista Ilana Casoy oferece uma narrativa investigativa sobre a biografia de diversos assassinos em série, na qual relata as histórias, contextos sociais e ações criminais que foram repercutidas da imprensa nacional, além de povoarem e aterrorizarem a imaginação popular. Em temporalidades distintas, a autora destacou personagens como José Augusto do Amaral, apelidado de "Preto Amaral"; Benedito Moreira de Carvalho, o "Monstro de Guaianases"; Francisco Costa Rocha, o "Chico Picadinho" e outras narrativas que compõem uma parcela da história criminal brasileira. Há um debate proposto em pensar, a partir de uma visão macroestrutural, a categoria de pertencimento desses indivíduos na sociedade, suas condições psicológicas e qual seria o papel do Estado no cuidado com a saúde mental dessas pessoas. Entre os nomes elencados, Febronio Indio do Brasil despertou nosso interesse durante a pesquisa, especialmente pela constituição de um debate médico-científico nos anos de 1920. 
Tenente, Teborde Simões de Mattos Indio do Brasil, Fabiano Indio do Brasil, Pedro de Souza, Pedro João de Souza, José de Mattos, Febronio Simões de Mattos e Bruno Ferreira Gabina, foram nomes utilizados por Febronio Indio do Brasil - nome pelo qual ficaria mais conhecido -, dono de uma extensa ficha criminal que "[...] incluía 37 prisões pela polícia, oito entradas na Casa de Detenções e três condenações. Havia sido preso por vadiagem, furto, roubo, chantagem e fraude" (CASOY, 2009, p. 47). Nesse subtítulo, propomos investigar mais profundamente o perfil e a história de Febronio, principalmente quando seus crimes começam a frequentar o noticiário do impresso periódico carioca Correio da Manhã, jornal popular que circulou no período de 1901 a 1974. Tentaremos demonstrar que o histórico criminal em diversas áreas ajudou a construir a imagem de um "criminoso nato" ou com raízes de uma "hereditariedade criminosa". Ao averiguarmos seus passos em quase uma década de narrativas criminais no Correio da Manhã, o periódico pode fornecer pistas da construção da sua imagem enquanto um criminoso hereditário e em evolução.

Esse ponto deve ser anotado, pois Febronio não aparece na história criminal consolidado desde o início como um assassino em série. Na verdade, seu histórico é recheado de outras ações. Em sua narrativa, Casoy relata que ao averiguar um dos locais em que esteve alojado durante sua vida, em Petrópolis, os vizinhos contaram que Febronio se passava por um dentista de nome "Dr. Bruno Ferreira Gabina" ${ }^{2}$, possuindo instrumentos profissionais e fazendo atendimentos regulares. ${ }^{3}$ Febronio, portanto, não vem à luz do crime com os assassinatos, mas com uma vida projetada em outros delitos.

O apelido de "Filho da Luz", usado como subtítulo, refere-se a um aspecto particular de sua história, pois Febronio havia criado uma religião e uma mitologia particular. Segundo ele, sua missão no mundo era tatuar meninos com a sigla DCVXVI (Deus, Caridade, Virtude, Santidade)4. Esta seria uma das justificativas pelos atos que

\footnotetext{
2 Ilana Casoy salienta que o verdadeiro dono do nome havia desaparecido em 1922.

3 Entre os casos mais exóticos, conta-se que extraiu dentes saudáveis de uma mulher de nome Francisca com a justificativa de que "dentes doentes comprometiam a integridade dos vizinhos" e, portanto, deveriam ser arrancados. Posteriormente, fizera a mulher realizar um bochecho com álcool puro na sua frente. Além disso, atuou também como médico e parteiro sob o nome de Dr. Uzeda Filho do qual se suspeita da morte de uma mulher em suas mãos (CASOY, 2009, p.51).

${ }^{4} \mathrm{~A}$ letra $\mathrm{X}$ significaria Santidade. Segundo ele, ainda, o inscrito traduziria: "Deus Vivo, ainda que com
} 
realizou com jovens do sexo masculino de diferentes idades. Segundo outro autor que elaborou estudo sobre o caso, João Silvério Trevisan, Febronio era leitor do livro bíblico de Daniel, possuía fama de feiticeiro e fazia previsões futurísticas (TREVISAN, 2004, p. 196). Dotado de uma retórica convincente, seu principal álibi era oferecer empregos a jovens ou familiares de meninos que precisavam de uma renda. Persuadia suas vítimas a acompanhá-lo até lugares longínquos onde sofriam tentativas de violência sexual, física, inscrições das tatuagens religiosas e, às vezes, a ação terminava em morte.

Febronio foi assunto frequente nos noticiários de impressos periódicos no ano de 1927, período em que o assassinato do menino João Ferreira, apelidado de Jonjoca, receberia comoção popular. Caracterizado pelos familiares da vítima como um homem "moreno, com dente de ouro e jaquetão escuro" (CASOY, 2009, p. 45), foi capturado, e internado no Manicômio Judiciário do Rio de Janeiro. Mais tarde, em 1935 conseguiria realizar uma fuga, mas foi novamente preso. Morreu com aproximadamente 89 anos.

A análise sobre crimes em impressos periódicos nos oferece a dimensão de "popularidade" desse gênero informativo. Desde a virada do século XIX para o XX, alguns periódicos da imprensa nacional vinculavam em suas páginas os fait divers com relação às noticiais criminais, "pois o empréstimo de recursos da ficção para tornar a notícia a um só tempo mais interessante ao leitor e menos violenta, amenizando a cena de sangue com recursos narrativos", expõe o estudo de Valéria Guimarães (2007, p. 324).

Um estudo que proporciona uma direção para este debate está na tese de Ana Vasconcelos Ottoni (2012, p. 39-41), ao mostrar que a notícia sensacional tinha como intenção induzir sentimentos nos leitores. Tanto as adjetivações, quanto a forma narrativa acusatória, poderiam ser utilizadas na caracterização dos "crimes de sensação". A descrição bem elaborada, com construções em detalhes excepcionais do crime, possibilitava ao leitor uma imersão naquela cena criminal. Com relação a Febronio, isso perece ter sido fundamental para explorarem uma conduta criminosa hereditária através de sua história, uma vez que sua permanência nas páginas policiais foi variada. Um mapeamento das fontes do Correio da Manhã elucidará melhor nosso argumento. 
Febronio esteve nas preocupações da polícia e sociedade na década de 1920 e não à toa ocupou lugar destacado nas páginas de jornais. No Correio da Manhã, podem ser encontradas evidências que antecedem a data dos seus crimes de maior repercussão, em 1927. Esta fonte colabora para compreender a trajetória de Febronio que mais tarde seria utilizada para esclarecer um processo contínuo de "degenerescência". Por exemplo, em notícia do dia 15 de fevereiro de 1920, consta a divulgação dos primeiros passos de Febronio ao ser acusado de um crime de estelionato. A matéria explana que

[...] o réu Febronio Indio do Brasil, acusado de fantasiar a existência de uma companhia intitulada União Brasileira, com sede à rua da Constituição, n. 30, haver se apropriado das finanças prestadas por Antonio Tavares Junior, José Medeiros da Silva, Luiz Fernandes, Luiz Bolbi e Bernardino Lopes, os quais, atraídos pelos anúncios colocados nos jornais pelo acusado [...] (Correio da Manhã, 15 de fevereiro de 1920)

Posteriormente, encontramos o desfecho do caso no Correio da Manhã de 18 de maio de 1920: "Foi julgada improcedente a ação intentada contra Febronio Indio do Brasil, acusado de haver recebido de diversos indivíduos a titulo de fiança para empregados a quantia de $450 \$$ ". Febronio foi inocentado.

Em 5 de Junho do mesmo ano, Febronio novamente estamparia as páginas policiais do periódico sob o título: "Febronio estava ontem de Azar". A notícia relataria uma ação de Febronio ao tentar ludibriar outras pessoas na obtenção de vantagem própria. Seu histórico no crime estaria presente na matéria, uma vez que "Diz o malandro que é cirurgião dentista, mas todo o mundo sabe que isso é modéstia, porquanto o Febronio é - e há muito - catedrático na pirataria". Em consequência, foi autuado e "metido no xadrez", como narra o Correio da Manhã.

"Vendeu uma casa que não era sua" seria o título da matéria de 4 de dezembro de 1920 do Correio da Manhã. Agora, constaria que "Esse grande 'chantagista' conseguiu realizar apenas isto: Vendeu o prédio n. 74 da rua Joaquim Silva, de sua propriedade [Do Sr. Armando Vidal], sem seu consentimento". Com documentos falsos, Febronio teria conseguido vender uma propriedade que não era sua. Na edição do dia seguinte, ele 
ainda figuraria ao lado de outro "vigarista" de nome Zé Corrêa, que estaria aplicando diversos golpes e aterrorizando a sociedade. Mesmo enquanto esteve preso, Febronio seria assunto do Correio da Manhã, pois, em 1922, causaria um furor interno no presídio ao reclamar da alimentação.

Foram apresentados até o momento o que podemos resumir como os "pequenos delitos" de Febronio. Todavia, no ano de 1927, suas ações assumem outro patamar, principalmente porque surgem os casos de sequestros, tentativas de homicídios e violações sexuais. Com a chamada de: "Sois filho da Luz: As peripécias por que passaram um menor e um demente", o Correio da Manhã de 20 de março daquele mesmo ano descreveria o sequestro do menino Octávio Bernardes, que teria sido raptado por Febronio. O presente caso saltaria aos olhos, afinal, Febronio tentaria inscrever uma tatuagem no corpo do menino com os dizeres: "sois filho da luz". O garoto teria conseguido fugir e o periódico observaria que "Esse indivíduo tem os mais repugnantes precedentes e vai ser mandado recolher à Casa de Detenção". Quatro meses depois, em 20 de julho de 1927, o jornal veicularia uma pequena nota de três linhas ressaltando o desfecho do caso: "O juiz da $6^{\text {a }}$ vara criminal impronunciou Febronio Indio do Brasil, acusado como incurso no art. 194 do Código Penal".

No segundo semestre de 1927, Febronio iria de sequestrador a assassino. Agora, ele seria acusado de estrangular um menino de nome Alamiro José Ribeiro. Febronio se passou por um motorista à procura de jovens para trabalhar em sua companhia de viação fictícia. A vítima foi seduzida pela proposta de emprego e morta. No dia seguinte, Febronio assumiria o ato e uma longa matéria seria redigida com detalhes do caso. Daí em diante encontramos entre a data de 1 de setembro até a data de 18 de setembro mais de 20 notícias ou referências a Febronio. A personagem foi elevada a um problema social e, dia após dia, aos moldes de uma novela, novas informações comporiam as histórias de Febronio.

As repercussões dos crimes cometidos por Febronio figurariam no jornal nos três anos seguintes. Contudo, as notícias apresentam poucas informações adicionais que possam contribuir para este debate, com exceção de uma a ser mencionada. No Correio da Manhã do dia 9 de setembro de 1927, há uma proposta de se estudar o caso de 
Febronio sob a ótica da ciência e da criminologia, afinal: "Dificilmente, e felizmente, aparece entre nós um tipo tão completo de criminoso com os requintes do Febronio". A particularidade deste caso constituiu um convite para que a ciência interviesse na tentativa de decifrar as motivações do "Filho da Luz". A forma como Febronio passou de um simples estelionatário para um assassino em série que aterrorizou a sociedade era digna de estudo, sobretudo, para que outros "tipos" fossem identificados antes de chegarem a esse estágio.

Uma das facetas da interpretação dos estudos sobre Febronio foi referenciada pelo pesquisador Hildeberto Vieira Martins (2012) ao lembrar que a Escola de Nina Rodrigues era representada nessa discussão por meio de seus seguidores e "[...] foram capazes, em certas circunstâncias, de vaticinar e determinar qual era o verdadeiro lugar social daqueles sujeitos considerados 'perigosos'". Mariza Corrêa, em estudo sobre a Escola de Nina Rodrigues, denominado As ilusões da liberdade (1998), mostrou como a influência de Nina Rodrigues no aparato médico e na criminologia levou seus discípulos nas primeiras décadas do século XX a contemplar o indivíduo sob a tarjeta de produtos de investigação e busca de criminosos na sociedade a partir de distintos fatores físicos ou mentais 5 .

Entre as fontes utilizadas na confecção desse trabalho, uma nos chamou atenção para a análise médica da situação de Febronio. Seu caso esteve na mira do Boletim Antialcoolico, publicado e editado pela Liga Brasileira de Higiene Mental em junho de 1929. Trata-se de uma única página de um Boletim que tinha como objetivo mostrar os malefícios do alcoolismo para o indivíduo e sua hereditariedade. Porém, centralizar este personagem é, antes de mais nada, maximizá-lo enquanto um exemplo indesejável na sociedade e modelo para uma propaganda antialcoólica. Mais que isso, é transformar Febronio numa espécie de garoto propaganda das taras hereditárias, sobretudo aproveitando sua exponencial circulação em impressos periódicos voltados ao grande público e do medo que pairou sob suas ações.

\footnotetext{
${ }^{5}$ Ver também, CUNHA, 2002.
} 
O "garoto propaganda da degeneração"

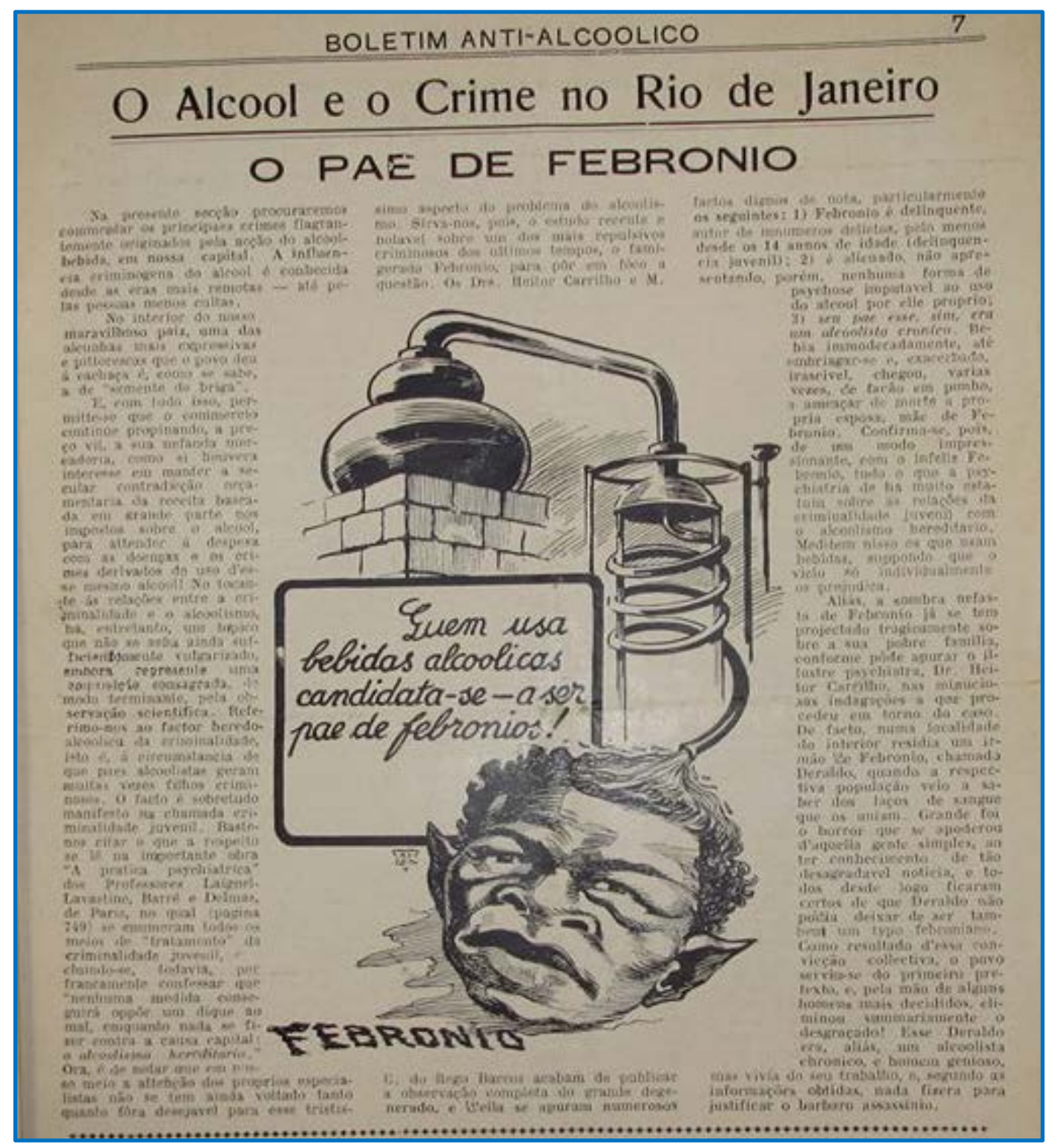

Imagem 1 - Boletim Anti-alcoolico. O Álcool e o Crime no Rio de Janeiro: O Pae de Febronio, Ano 1, n.1, 1929.

Com a frase "Quem usa bebidas alcoólicas candidata-se a ser pae de Febronios!" e o título O Álcool e o Crime no Rio de Janeiro: O Pae de Febronio (Boletim Anti-alcoolico, 1929, p. 7), o Boletim assinalava a preocupação médica e social dos riscos entre hereditariedade e consumo do álcool. Para ilustrar seus efeitos, o garoto propaganda foi o então conhecido assassino em série Febronio Indio do Brasil. De início, percebemos a implicação que a imagem de Febronio possuía no imaginário popular ao passo de ser considerado 
um representante legítimo das chamadas "taras hereditárias". À época, a sociedade conhecia os crimes de Febronio, assim como apresentamos em sua trajetória jornalística no Correio da Manhã. O ponto nevrálgico estaria na perspectiva de um indivíduo propenso a determinadas atitudes por conta dos seus vícios. Em outras palavras, o pai de Febronio seria o principal culpado por seu filho ter se tornado um assassino em série, pois seu vício alcoólico gerou um indivíduo "degenerado". A mensagem do Boletim era específica, a saber, qualquer consumidor da bebida poderia estar no lugar do pai de Febronio. $\mathrm{O}$ uso do álcool poderia gerar em sua descendência proles de assassinos ou as mais variadas combinações de criminosos.

O Boletim foi uma iniciativa editada pela Liga Brasileira de Higiene Mental, também responsável pelo periódico especializado Arquivos Brasileiros de Higiene Mental, em que uma das suas principais campanhas estaria no hastear de uma luta nacional antialcoólica. O pesquisador José Roberto Franco Reis (1994), ao se debruçar sobre o tema da Liga e eugenia, percebeu como o discurso de degeneração da bebida no corpo e na mente foi amplamente desenvolvido e atrelado aos escopos da Liga. Para tanto, ao longo de duas décadas (1920-1940), o periódico especializado da LBHM vinculou uma densa discussão sobre o tópico e quais seriam os prejuízos do consumo do álcool na constituição orgânica e moral da população, especialmente, na busca de um indivíduo e nação saudáveis.

Por seu turno, o Boletim configura mais um desses esforços da Liga na cruzada antialcoólica nacional. O ano de 1929 ainda pode ser lembrado como um período em que este debate era amplamente discutido em ambientes médicos, sociais e políticos. Não à toa, podemos notar que entre as propostas do Primeiro Congresso Brasileiro de Eugenia, realizado naquele mesmo ano, boa parte de suas resoluções estaria na ampliação das estratégias de combate ao alcoolismo.

Na crítica à fonte, em primeiro lugar, pode-se observar uma preocupação com a facilidade da venda de bebidas alcoólicas para qualquer pessoa. Ao se referirem à cachaça como "a semente da briga", o impresso estabelece a relação facilitadora entre venda, aceitação do governo em torno das taxações e os problemas de desordem pública gerados pelo seu consumo. Posto o problema econômico de modo introdutório, o tópico dissertaria acerca da sua principal preocupação: 
Referimo-nos ao fator heredoalcoolico da criminalidade, isto é, a circunstâncias de que pais alcoolistas geram muitas vezes filhos criminosos. O fato é sobretudo manifesto na chamada criminalidade juvenil. Baste-nos citar o que a respeito se lê na importante obra "A pratica psychiatrica" dos Professores Laignel-Lavastine, Barré e Delmas, de Paris, no qual (página 749), se enumeram todos os meios de "tratamento" da criminalidade juvenil, incluindo-se todavia, por francamente confessar que "nenhuma medica conseguirá opor um dique ao mal, enquanto nada se fizer contra a causa capital: o alcoolismo hereditário". (Boletim Anti-alcoolico, 1929, p. 7)

Inicialmente constata-se a predominância das teses neolamarckistas para compreensão do indivíduo e o uso do álcool. Afinal, partindo da crença de que o ambiente modelaria os caracteres hereditários, aquele que consumisse uma substância nociva estaria transformando seu organismo e transferindo essas novas propriedades à sua prole. Como nos exemplos de Adda Jurke e do pai de Febronio, a utilização da bebida poderia desencadear o nascimento de uma prole "degenerada", sobretudo, com tendências criminais. A corrente neolamarckista foi chamada, enquanto teoria explicativa, para a compreensão da utilização do álcool e da degeneração na carga hereditária;uma leitura pertinente, à medida que esta tese estaria em pleno diálogo no meio médicoacadêmico. Nesse sentido, Fernando Sérgio Dumas Santos sublinha, por exemplo, que:

[...] outra corrente argumentava que, se os genitores eram alcoolistas, mas o pai, embora fosse um "alcoolista crônico, não bebesse nada no dia da concepção da criança; e a mãe observasse a mais completa abstinência durante a gravidez, o feto não deveria sofrera a influência do álcool em período algum da vida intra-uterina. Estes médicos perguntavam-se, então, se esta criança carregaria "a lei da hereditariedade alcoólica". (SANTOS, 1995, p. 135)

Embora o uso do álcool pela mulher exerça papel basilar na formação da criança no período de gestação, o consumo pelo pai e a possibilidade de transmissão de caracteres de um "produto degenerado" por meio da relação sexual tomava maior ênfase em tais discursos. Na interpretação do Boletim, o homem seria colocado no centro do discurso do álcool e da degeneração, e, portanto, no presente estudo de caso ela explicaria a relação do consumo de álcool do pai de Febronio e as consequências da 
transmissão hereditária. Observa-se uma curiosa tentativa de intimidar o consumo do álcool colocando em xeque a responsabilidade do sexo masculino no uso da bebida. Dessa forma, a imagem de Febronio enquanto "garoto propaganda" calha na medida em que o temor das suas atitudes era presente na sociedade. Assim, o Boletim utilizou, como estratégia para a luta antialcoólica, o medo do consumidor da bebida em se tornar uma espécie de "repositório de degenerados".

Em vista das discussões médicas e científicas da época, o Boletim alude ao debate proposto pelos intelectuais Heitor Carrilho - diretor do Manicômio Judiciário - e Manoel Clemente Rego Barros, no qual discutiam em recente estudo o conceito de "o grande degenerado". Em pauta, foi objetivada a condição de Febronio como um indivíduo criminoso desde os seus 14 anos. É destacado que Febronio não possuía vícios em bebidas alcoólicas, mas, seu pai, era caracterizado como um alcoolista crônico. Este, "Bebia imoderadamente, até embriagar-se e, exacerbado, irascível, chegou, várias vezes, de facão em punho, a ameaçar de morte a própria esposa, mãe de Febrônio". Em resumo, a conclusão do estudo demonstrava ao leitor que mesmo um indivíduo sem vícios poderia carregar as marcas de sua descendência "degenerada". Aquele que optasse pelo consumo do álcool deveria estar ciente das consequências, e de que poderia colocar em risco toda uma geração futura. Quando Carrilho e Rego Barros comentam sobre a criminalidade de Febronio desde a sua juventude, confirmam aquela ideia trabalhada por nós, a partir das fontes de Correio da Manhã, acerca de um indivíduo propenso à criminalidade por conta da sua hereditariedade.

Ainda nas discussões médicas e psiquiátricas, o Correio da Manhã publicou em 17 de fevereiro de 1929 uma entrevista com o estudioso Mauricio Urstein, autor do livro Criminalidade e Psicose (1930), que esteve in loco com o Dr. Heitor Carrilho e foi apresentado ao caso de Febronio. Seu diagnóstico sobre Febronio era caracterizado como "heboidophrenía" e que isso constituía "[...] uma psicose que começa na infância, ou na idade adulta e se caracteriza pelo desvio do senso moral e dos outros costumes, bem como pela tendência a atos criminosos". Para ele, Febronio nutria tendências criminosas que se desenvolveram ao longo da sua vida. Sua conclusão pontuava que este "tipo" de indivíduo deveria ser resguardado em um manicômio perpétuo de forma "a 
sequestrá-lo da sociedade". Percebe-se uma movimentação de parte da intelectualidade médica e psiquiátrica na tentativa de compreender o caso de Febronio.

Ao analisar a trajetória de Heitor Carrilho, o pesquisador Allister Dias relatou que o caso de maior repercussão e impacto social que o médico psiquiatra trabalhou foi o de Febronio. Referente à situação de Febronio, Carrilho "quis demonstrar, na ocasião, que o ato antissocial seria presumível em certas pessoas, no geral reincidentes, criados num meio cultural que naturaliza o crime e portadores de anormalidades psico-biológicas" (DIAS, 2015, p. 384).

Outro ponto a ser destacado no Boletim diz respeito à família de Febronio, especialmente quando identificaram seu irmão, Deraldo. O problema está inserido na constatação de que Deraldo também poderia carregar um "tipo Febronio" de criminalidade. À luz daquela discussão médico-científica, a conclusão parecia evidente, afinal, se Febronio era um assassino derivado de um mal hereditário transmitido por seu pai, igualmente, todos aqueles gerados do mesmo indivíduo comporiam o quadro de propensos criminosos. A consequência social do medo foi draconiana: "Como resultado dessa convicção coletiva, o povo serviu-se do primeiro pretexto, e, pela mão de alguns homens mais decididos, eliminou sumariamente o desgraçado!".

Segundo o estudo de Pedro Ferrari, Deraldo foi morto por ser considerado um indivíduo que poderia tornar-se um "Febrônio". À época em que o laudo de Febrônio era confeccionado, seu outro irmão, Agenor Ferreira de Matos visitou o Manicômio Judiciário e relatou algumas questões interessantes sobre Deraldo e a vida pessoal de seu pai. Em relação a Deraldo, diria que "era um homem trabalhador e, se bem que genioso e dado ao uso imoderado do álcool, nada fizera para justificar o bárbaro assassinato de que foi vítima" (FERRARI, 2013, p. 219). Por sua vez, no que concerne ao seu pai afirmou: "Fazia uso do álcool. Possuía efetivamente um temperamento impetuoso e violento; brigava com frequência com a sua mãe e muitas vezes, facão em punho, pretendeu matá-la" (FERRARI, 2013, p. 219). A hereditariedade foi um ponto proeminente na tentativa de desvendar este enigma que era Febronio, principalmente trazendo à tona a relação entre alcoolismo e a sua descendência familiar. Assim, seu irmão foi eleito como uma espécie de "Febronio incubado" motivando receio e resposta social. 
O indício de um mal transmitido hereditariamente, advindo do ambiente, esteve presente nas concepções de grupos médicos que adotavam como forma de compreensão científica a corrente neolamarckista. Como citamos ao longo do texto, na concepção do uso do álcool, a teoria se enquadrava à medida que a substância modificava e degenerava o organismo e transmitia essa degeneração para as gerações subsequentes. Por esta ótica, Nancy Stepan (2005, p. 100) anota que visto como um mal social e degenerador da raça, sua ação comprometeria "[...] condições hereditárias ligadas ao crime, à delinquência juvenil, à prostituição e às doenças mentais, e porque seus efeitos afetavam várias gerações subsequentes".

Devemos dialogar com o contexto social do período para observarmos os rumos do caso de Febronio. Como mencionados anteriormente, tanto Michel Foucault como Sidney Chalhoub, cada um ao seu modo, asseveraram sobre a construção de "certos padrões" que seriam alvos de medidas específicas, tanto no ambiente médico e psiquiátrico como na política. Foucault demonstrou que o considerado "louco" tinha um determinado perfil eleito, aliado ao abandono das formas da ética burguesa. Chalhoub nomeou de "classes perigosas" indivíduos pobres e negros que sofriam perseguições no Brasil. Isso significa que devemos observar outras questões presentes no contexto brasileiro para entender o lugar de Febronio. Além de um potencial "degenerado" por uma questão hereditária, o famoso assassino em série era negro. Apesar da fonte não utilizar o argumento da cor e raça como pressuposto, o discurso fazia parte das discussões raciais da época, pois o negro seria visto como um potencial criminoso.

Na mesma linha de raciocínio, outro fator muito debatido no período era acionado: a homossexualidade. Era sabido que Febronio violentava sexualmente suas vítimas - meninos -, e tais ações eram descritas como uma de suas características. No bojo da discussão, o pesquisador Hildeberto Vieira Martins (2012) aborda o tema ao dizer que "Para Leonídio Ribeiro, o caso de Febronio era ímpar, dado o seu ineditismo no Brasil. Essa raridade devia-se, segundo ele, por se tratar de um caso de sadismo ('homossexualismo') e de ser o seu representante um 'mestiço' (RIBEIRO, 1938, p. 119)". Ou seja, a análise da cor e homossexualidade de Febronio também foram relativizadas na amplitude da discussão. 
O signo da mestiçagem estaria presente naquilo que Ricardo Ventura Santos chamou (2010, p. 104) de nation-building brasileiro. Isto é, a discussão sobre como um modelo de nação faria parte dos debates científicos a respeito de "tipos humanos" idealizados, especialmente condizente com a cor de sua população. A ciência, por sua vez, seria instrumentalizada para oferecer explicações e resoluções para determinadas assimetrias de parte da população brasileira, caracterizada pela heterogeneidade de seu povo. O negro e o miscigenado, neste caso, eram peças participantes de um longo debate que iria desde restrições imigratórias até os diagnósticos dos malefícios da mistura racial para a criação quase que laboratorial do brasileiro "desejado".

No que concerne à homossexualidade, Peter Fry dedicou uma parte de sua reflexão para estudar o caso de Febronio em O que é Homossexualidade (FRY, 1985, p. 66). Ao relatar a visão do médico e discípulo de Afrânio Peixoto, Leonídio Ribeiro sobre Febronio, dissertou:

\begin{abstract}
Mas, com a mudança do status da "homossexualidade" de pecado para "doença", abre-se a possibilidade de cura. A partir dos argumentos de Ribeiro, por exemplo, Febronio a "salvo" da cadeia e premiado com a segregação ad vitam no Manicômio Judiciário. E todos os homens classificados como "homossexuais" são agora sujeitos ao tratamento "medico pedagógico". Diz Ribeiro: "Provado que o homossexualismo e, em grande numero de casos, uma conseqüência de perturbações do funcionamento das glândulas de secreção interna, logo surgiu a possibilidade de seu tratamento. Era mais um problema social a ser resolvido pela medicina".
\end{abstract}

Outro autor que se debruçou sobre a relação entre Febronio e a homossexualidade, João Silvério Trevisan (2004, p. 198-199) indica que as interpretações variadas do contexto do assassino em série não deixam dúvidas com relação à sua sexualidade. Heitor Carrilho fundamentaria suas conclusões elaborando o parecer no qual Febronio deveria ser isolado da sociedade para sempre por se tratar de uma "anormalidade constitucional". Mais ainda, sua homossexualidade sádica era perigosa para a sociedade. Como afirma Trevisan, Febronio receberia eletrochoques e compostos químicos como forma de tratamento. Ele seria uma representação de "louco moral", ou, no máximo, receberia o status de "Uma relíquia do Manicômio Judiciário". 
Este quadro geral expõe a crença na ciência para resolver os problemas da sociedade, especialmente aqueles de ordem desviante do indivíduo. Um debate que esteve frequente nas falas de criminologistas e adeptos do discurso do "indivíduo degenerado". O final da década de 1920 elevou Febronio como uma espécie de "garoto propaganda da degeneração", pois além de ter sua hereditariedade comprometida, fruto do vício do seu pai, ele também era homossexual e negro, duas categorias em profundo debate no contexto da época.

\section{Considerações finais}

Jack, "The Ripper" ou Febronio, "Filho da Luz", são personagens cronologicamente distantes, mas que igualmente causaram impacto e medo nas sociedades em que habitaram. Além disso, ambos suscitaram debates em torno da fabricação do indivíduo "corrompido", em que havia a necessidade de explicar, identificar e criar estratégias para o encarceramento de possíveis criminosos. À ciência, caberia fornecer as estratégias de identificação e proporcionar instrumentos que facilitassem diagnósticos e capturas. Ou ainda, quem sabe, "repará-los".

As tentativas na identificação de um "padrão de degenerados" são diversas, bem como suas motivações e soluções propostas. O álcool estaria enquadrado como um dos fatores que poderia danificar a hereditariedade humana e, não à toa, campanhas foram criadas na contenção de sua disseminação na sociedade. O pesquisador argentino Diego Armus (2007, p. 181), relata a questão alcoólica observada enquanto problema social e percebeu a ligação entre álcool, degeneração e tuberculose em periódicos argentinos como El Obrero Panadero em que: "el alcohol embrutece, degenera los sentidos y denigra; produce querellas, disensiones, crímenes, miserias, enfermedades, locura, prepara el cuerpo para la tisis y la tuberculosis" ${ }^{6}$. Elevado a motivo de preocupação social, o álcool comporia diversos estudos que dariam conta de explicar, sobretudo acionando o modelo neolamarckista, as formas com que o indivíduo poderia comprometer toda a sociedade e sua descendência por meio do uso da bebida.

\footnotetext{
${ }^{6}$ Grifo nosso.
} 
Nesses termos, o caso de Febronio foi sintomático no final dos anos de 1920, em meio às discussões que pretendiam coibir a circulação de bebidas alcoólicas na sociedade. Estelionatário, criminoso em várias áreas, sequestrador, assassino, Febronio era o "tipo" perfeito para servir de exemplo, por isso era necessário estudá-lo e propagandeá-lo. Tornou-se um exemplo, inclusive, para as propostas que visavam taxar economicamente o álcool, fazendo com que fosse mais difícil adquiri-lo e consumi-lo.

O texto do Boletim Anti-alcoolico contribui, ainda, para percebermos a relevância de correntes teóricas em plena controvérsia científica naqueles momentos como o neolamarckismo e o mendelianismo. Sendo o ambiente um fator modificador da hereditariedade para os defensores do neolamarckismo, o consumo do álcool apresentava elementos conclusivos para caracterizá-lo como responsável pela "degeneração". Febronio, mais uma vez, seria apontado como modelo. Como pontuou o historiador Henrique Carneiro, as autoridades constituíram as ferramentas para estabelecer o que poderia ou não ser consumido e "padronizado". Em nosso caso, as legitimações médica e psiquiátrica funcionavam enquanto autoridades para o controle social. Para Carneiro (2005, p. 21) "O que comer, que remédio tomar, como se divertir, como enfrentar a dor. A questão política é a definição do âmbito da auto-regulação do indivíduo". Febronio pode ser lido como um instrumento de autorregulação para a sociedade da sua época.

Ademais, a imagem de Febronio constituiu um exemplo dos malefícios do uso do álcool para a sociedade em geral. O perfil do homem sóbrio, sem vícios, seria defendido por uma parcela médica e psiquiátrica aliada às correntes teóricas específicas que propunham o ambiente como modificador da hereditariedade. Portanto, nutriram a crença dos vícios hereditários e excluiriam o consumo da bebida em seus projetos de nação. Por essa perspectiva, o Boletim Anti-alcoolico faria o alerta sobre as consequências do vício e a possibilidade do usuário danificar a sua estirpe e transmitir para a nação os genes do "grande degenerado". 


\section{Referências}

ARMUS, Diego. La ciudad impura. Buenos Aires: Edhasa, 2007.

BLACK, Edwin. Guerra contra os fracos: a eugenia e a campanha dos Estados Unidos para criar uma raça dominante. São Paulo: A Girafa Editora, 2003.

Boletim Anti-alcoolico. O Álcool e o Crime no Rio de Janeiro: O Pai de Febronio, Ano 1, n.1, 1929.

CANGUILHEM, George. O normal e o patológico. $6^{\text {a }}$ ed. Rio de Janeiro: Editora Forense Universitária, 2009.

CAPONI, Sandra. Loucos e degenerados: uma genealogia da psiquiatria ampliada. Rio de Janeiro: Editora FIOCRUZ, 2012.

CARNEIRO, Henrique. Transformações do significado da palavra "droga": das especiarias coloniais ao proibicionismo contemporâneo. In: CARNEIRO, Henrique; Venâncio, Renato Pinto. Álcool e drogas na história do Brasil. São Paulo: Alameda; Belo Horizonte: Editora PUCMinas, 2005.

CARRARA Sérgio. Crime e loucura: o aparecimento do manicômio judiciário na passagem do século. Rio de Janeiro: EdUERJ; São Paulo: EdUSP, 1998.

CARRARA Sérgio. Tributo a Vênus: a luta contra a sífilis no Brasil, da passagem do século aos anos 40. Rio de Janeiro: FIOCRUZ, 1996.

CASOY, Ilana. Serial Killers made in Brasil. Rio de Janeiro: Ediouro, 2009.

CHALHOUB, Sidney. Cidade febril: cortiços epidemias na corte imperial. São Paulo: Companhia das Letras, 1996.

CORRÊA, Mariza. As ilusões da liberdade: a Escola Nina Rodrigues e a antropologia no Brasil. Bragança Paulista: EdUSF, 1998.

Correio da Manhã, 15 de fevereiro de 1920, p. 4.

Correio da Manhã, 18 de maio de 1920, p. 4.

Correio da Manhã, 5 de junho de 1920, p. 4.

Correio da Manhã, 4 de dezembro de 1920, p. 4. 
Correio da Manhã, 4 de dezembro de 1920, p. 5.

Correio da Manhã, 14 de fevereiro de 1922, p. 5.

Correio da Manhã, 20 de março de 1927, p. 7.

Correio da Manhã, 20 de julho de 1927, p. 5.

Correio da Manhã, 1 de setembro de 1927, p. 3.

Correio da Manhã, 2 de setembro de 1927, p. 3.

Correio da Manhã, 3 de setembro de 1927, p. 5.

Correio da Manhã, 9 de setembro de 1927, p. 3.

Correio da Manhã, 17 de Fevereiro de 1929.

CUNHA, Olívia Maria Gomes da. Intenção e gesto: pessoa, cor e a produção cotidiana da (in)diferença no Rio de Janeiro, 1927-1942. Rio de Janeiro: Editora Arquivo Nacional, 2002.

DIAS, Allister Andrew Teixeira. Arquivos de ciências, crimes e loucuras: Heitor Carrilho e o debate criminológico do Rio de Janeiro entre as décadas de 1920 e 1940. 2015. Tese (Doutorado em História das Ciências e da Saúde) - Fundação Instituto Oswaldo Cruz, Casa de Oswaldo Cruz, Rio de Janeiro, 2015.

FERRARI, Pedro Felipe Marques Gomes. Mosaicos do filho da luz: Febrônio Índio do Brasil entre o crime, a redenção e o delírio. 2013. Tese (Doutorado em História) - Universidade de Brasília, Brasília, 2013.

FOUCAULT, Michel. História da loucura na idade clássica. São Paulo: Perspectiva/Éditions Gallimard, 1972.

FRY, Peter. Febrônio Indio do Brasil: onde cruzam a psiquiatria, a profecia, a homossexualidade e a lei. In: EULÁLIO, Alexandre et al. Caminhos cruzados: linguagem, antropologia e ciências naturais. São Paulo: Brasiliense, 1982.

FRY, Peter.. O que é homossexualidade. São Paulo: Abril Cultural Brasiliense, 1985. 
GOMES, Ana Carolina Vimieiro. Um programa de "sciencia do Brazil": a inserção da fisiologia experimental na agenda científica brasileira em fins do século XIX (1880-1889). 2009. Tese (Doutorado em História) - Universidade Federal de Minas Gerais, Belo Horizonte, 2009.

GUIMARÃES, Valéria. Os dramas da cidade nos jornais de São Paulo na passagem para o século XX. Revista Brasileira de História. São Paulo, v. 27, n. 53, p. 323-349, 2007.

GUTMAN, Guilherme. Febronio, Blaise \& Heitor. Pathos, violência e poder. Latinoam. Psicopat. Fund., São Paulo, v. 13, n. 2, p. 175-189, 2010.

KEHL, Renato. Eugenia e Medicinal Social. Rio de Janeiro: Francisco Alves, 1923.

LOMBROSO, Cesare. Criminal Man. New York: The Knickerbockers Press, 1911.

MARTINS, Hildeberto Vieira. O discurso médico-psicológico e a garantia dos "efeitos salutares e elevados da defesa social": o "caso Febronio". In: ENCONTRO REGIONAL DE HISTÓRIA OFÍCIO DO HISTORIADOR: ENSINO \& PESQUISA, XV, Rio de Janeiro, RJ, 2012. Anais... Rio de Janeiro: ANPUH, 2012.

OTTONI, Ana Vasconcelos. "O Paraíso dos ladrões": crime e criminosos nas reportagens policiais da imprensa (Rio de Janeiro, 1900-1920). 2012. Tese (Doutorado em História Social) - Universidade Federal Fluminense, Rio de Janeiro, 2012.

REIS, José Roberto Franco. Higiene mental e eugenia: o projeto de "regeneração nacional” da Liga Brasileira de Higiene Mental (1920-1930). 1994. Dissertação (Mestrado em História) - Universidade Estadual de Campinas, 1994.

SANTOS, Fernando Sergio Dumas dos. Alcoolismo: a invenção de uma doença. Dissertação de Mestrado. Campinas-SP: UNICAMP, 1995.

SANTOS, Fernando Sergio Dumas dos;VERANI, Ana Carolina. Alcoolismo e medicina psiquiátrica no Brasil do início do século XX. Hist. Cienc. Saude-Manguinhos [online]. v.17, supl.2, p. 400-420, 2010.

SANTOS, Ricardo Ventura. Mestiçagem, Degeneração e a Viabilidade de uma Nação: debates em antropologia física no Brasil (1870-1930). In: MAIO, Marcos Chor; SANTOS, Ricardo Ventura (Orgs.). Raça como questão: história, ciência e identidades no Brasil. Rio de Janeiro: Editora FIOCRUZ, 2010.

STEPAN, Nancy L. A hora da eugenia: raça gênero e nação na América Latina. Rio de Janeiro: Ed. Fiocruz, 2005. 
TREVISAN, João Silvério. Devassos no paraíso: (a homossexualidade no Brasil, da colônia à atualidade). $6^{\mathrm{a}}$ Ed. Rio de Janeiro: Record: 2004. 